\title{
Detergents Effect on Egg Hatchability, Morphometry and Larval Bone Structure of Native Indonesian Fish: Wader Pari (Rasbora lateristriata Bleeker, 1854)
}

\author{
Farahsani Umi Abida ${ }^{1}$, Parvez Alam ${ }^{2}$ and Bambang Retnoaji ${ }^{1, *}$ \\ ${ }^{1}$ Faculty of Biology, Universitas Gadjah Mada, Jl. Teknika Selatan, Senolowo, Sinduadi, \\ Yogyakarta 55281, Indonesia \\ ${ }^{2}$ School of Engineering, Institute of Material and Processes, The University of Edinburgh, \\ Edinburgh EH9 3FB, United Kingdom
}

\begin{abstract}
This study was conducted to determine the effect of detergents on eggs hatchability, survival rates, morphometry and bone structure of Wader Pari fish (Rasbora lateristriata Bleeker, 1854). The fish were treated with detergent solution, with a concentration of $0 \mathrm{mg} \mathrm{L}^{-1}, 3 \mathrm{mg}$ $\mathrm{L}^{-1}, 6 \mathrm{mg} \mathrm{L}^{-1}, 9 \mathrm{mg} \mathrm{L}^{-1}, 18 \mathrm{mg} \mathrm{L}^{-1}, 27 \mathrm{mg} \mathrm{L}^{-1}$, and $50 \mathrm{mg} \mathrm{L}^{-1}$, respectively. Each test consisted of one aquarium filled with 30 eggs. The number of eggs hatched was counted and these were treated continually for 1.5 mo to determine fish survival rates, morphology, growth rates and bone structure assays. The bone structure assay was prepared with Alizarin's Red-Alcian Blue staining. The results show that detergent treatments at $0 \mathrm{mg} \mathrm{L}^{-1}, 3 \mathrm{mg} \mathrm{L}^{-1}, 6 \mathrm{mg} \mathrm{L}^{-1}, 9 \mathrm{mg} \mathrm{L}^{-1}$ did not significantly affect hatchability, survival rate, or morphometry of either egg or fish ( $\mathrm{p}>$ 0.05). However, a higher concentration at $18 \mathrm{mg} \mathrm{L}^{-1}, 27 \mathrm{mg} \mathrm{L}^{-1}$, and 50 $\mathrm{mg} \mathrm{L}^{-1}$, significantly affected the fish egg hatchability and survivability. Moreover, fish vertebral structures were normal at treatments of $0 \mathrm{mg} \mathrm{L}^{-1}$, $3 \mathrm{mg} \mathrm{L}^{-1}, 6 \mathrm{mg} \mathrm{L}^{-1}$, whereas at $9 \mathrm{mg} \mathrm{L}^{-1}$, was caused abnormal vertebral structures.
\end{abstract}

Keywords: Fish, larvae, water polution, survival rate, vertebrae

\section{Introduction}

Detergents are cleaning products that are a cause for environmental concern as they may be leached into rivers, especially where water pollution control is not well regulated. The laundry industry is a sector that utilizes detergents in high quantities, and the rates of utility are on an upward trajectory. The number of licensed and supervised laundry services in the Yogyakarta region, Indonesia are currently only $96 \%$ [1]. However, its estimated that this number will multiply rapidly, especially as home-scale laundry outlets gain popularity. Most home-scale laundry services lack effective waste disposal facilities for the treatment and disposal of their waste. As such, laundry waste is typically released directly into local open water sources such as rivers and streams [1].

\footnotetext{
* Corresponding author: bambang.retnoaji@ugm.ac.id
} 
Important constituents in detergents include surfactants, builders, organic additives, solvents, enzymes, and stains. Surfactant is the most important and active component in detergents. One example of the most widely used surfactant is LAS (Linear Alkylbenzene Sulfonate). LAS, contains a long chain of carbon atoms, which cannot be degraded by microorganisms [2-5]. Detergent enzymes usually account for $2 \%$ of their total weight. LAS decreases the stability of detergent proteases [3].

Detergents in water are absorbed by fish through their gills or skin, affecting proteins, fats and carbohydrates content [6]. The fish egg and larval phase is the most sensitive stage for water pollution.

Detergent can destroy fish eggs at a specific concentration, before the gastrulation stage of the embryo is more susceptible to pollutant stress compared to the embryo which has completed the gastrulation $[7,8]$. The increasing concentration of surfactants in the waters can also result in a decrease in surface tension of the egg membrane so that the surfactant easily penetrates the egg thus disturbing the egg metabolisms. The detergent is also able to inhibit several enzyme systems by suppressing egg respiration, which results in oxygen starvation, leading to egg mortality. Moreover, the detergent can interfere with the pattern of axis formation, and head and eye development, respectively [2].

Detergent can also affect adult fish. Amount $3 \mathrm{mg} \mathrm{L}^{-1}$ detergent can reduce the blood protein content of Cirrhinus mrigala [Hamilton, 1822] fish from $3.14 \mathrm{mg} \mathrm{dL}^{-1}$ to $1.28 \mathrm{mg}$ $\mathrm{dL}^{-1}$ within the space of $72 \mathrm{~h}$. This decrease may inhibit protein synthesis to the detriment of the formation of bone matrices, which in turn could lead to vertebral column abnormalities. Detergent and surfactant exposure may furthermore cause liver cell defects and have locomotory effects on fishes [2, 9-11]. Given that wader pari fish may be adversely affected by the growing concentrations of detergents in water, research to determine the specific effects of detergents on eggs in terms of hatchability, survival rate, morphometry and bone structure, is urgently needed.

\section{Materials and methods}

\subsection{Fish reproduction and egg collection}

Female and male fish with mature gonad were selected and maintained at the laboratory, with adequate food, as well as controlled environmental conditions of $16 \mathrm{~h}$ bright photoperiod cycle and $8 \mathrm{~h}$ dark, $28{ }^{\circ} \mathrm{C}$ to $29^{\circ} \mathrm{C}$ of temperature, and at a $\mathrm{pH}$ of 7.0 to 7.5. Soon after spawning was conducted, the fish were returned to the initial aquarium, and eggs were collected, cleaned and maintained on egg water for further treatment.

\subsection{Egg treatment}

Eggs were put in aquariums using 30 eggs for each treatment. The setup of media were $0 \mathrm{mg} \mathrm{L}{ }^{-1}, 3 \mathrm{mg} \mathrm{L}^{-1}, 6 \mathrm{mg} \mathrm{L}^{-1}, 9 \mathrm{mg} \mathrm{L}^{-1}, 18 \mathrm{mg} \mathrm{L}^{-1}, 27 \mathrm{mg} \mathrm{L}^{-1}$, and $50 \mathrm{mg} \mathrm{L}^{-1}$ of detergent, with three replications at each concentration.

\subsection{Eggs hatchability}

After $24 \mathrm{~h}$ of treatment, eggs were observed and the number of hatched eggs was recorded in each treatment. Furthermore, the larvae were kept for about 2 mo. 


\subsection{Morphometry of the fish}

During 2 mo the larvae were observed for survivability and growth and these were also morphologically documented.

\subsection{Skeletal staining}

Fish bone staining was performed to detect the possible bone defects resulting from the treatment. Three fish from each treatment were randomly chosen for bone staining for Alizarin's Red-Alcian Blue following Inouye [12], with modifications. Fish were fixed with $96 \%$ ethanol for $3 \mathrm{~d}$ and internal organs were removed. After fixation, embryos were treated with acetone for $24 \mathrm{~h}$ and then incubated in staining solution $(0.015 \%$ Alcian Blue, $0.015 \%$ Alizarin Red in $70 \%$ ethanol) at $37{ }^{\circ} \mathrm{C}$ for $3 \mathrm{~d}$ to $4 \mathrm{~d}$. After being washed with water, the embryos were cleared using $1 \% \mathrm{KOH}$ for $48 \mathrm{~h}$ to $72 \mathrm{~h}$ and successively incubated in $1 \% \mathrm{KOH}-20 \%$ glycerol. Stained embryos were stored and observed in $50 \%$ glycerol.

\subsection{Data analysis}

Quantitative data obtained from this study, such as percent of eggs hatchability, survival rates, and fish body ratios, were statistical analyzed with ANOVA.

\section{Results and discussions}

\subsection{Environmental parameter}

The water quality parameters were measured initially $24 \mathrm{~h}$ after treatment and the routinely each week, which included the temperature, $\mathrm{pH}$ and dissolved oxygen (Table 1). Overall, the water properties were similar for both the control and the treatment save the $\mathrm{pH}$ value during the first $24 \mathrm{~h}$ of treatment using $9 \mathrm{mg} \mathrm{L}^{-1}$, which has a $\mathrm{pH}$ value of 8 .

Table 1. The parameters of environmental condition measured during the experiment

\begin{tabular}{|c|c|c|c|c|}
\hline \multirow{2}{*}{ Water quality } & \multicolumn{2}{|c|}{ First $24 \mathbf{~ h}$} & \multicolumn{2}{c|}{ Weekly Average } \\
\cline { 2 - 5 } & control & treatment & control & treatment \\
\hline $\mathrm{pH}$ & 7 & 8 & 7 to 7.5 & 7 to 8 \\
\hline Temperature $\left({ }^{\circ} \mathrm{C}\right)$ & 28 & 28 & 27 to 30 & 27 to 30 \\
\hline Dissolved oxygen & 8 & 8 & 7 to 8 & 7 to 8 \\
\hline
\end{tabular}

The overall value of the whole period of the experiment was in a good range for egg hatching and larval development.

\subsection{Fish eggs hatchability}

The hatching rate of eggs treated with detergents in several concentrations is presented in Figure 1 . The hatching rate of the eggs in all treatments, ranged from $93.33 \%$ to $100 \%$. The lowest hatching percentage was on $3 \mathrm{mg} \mathrm{L}{ }^{-1}$, while the others reached $100 \%$ hatchability. However, overall treatment was not significantly different $(p=0.05)$. 


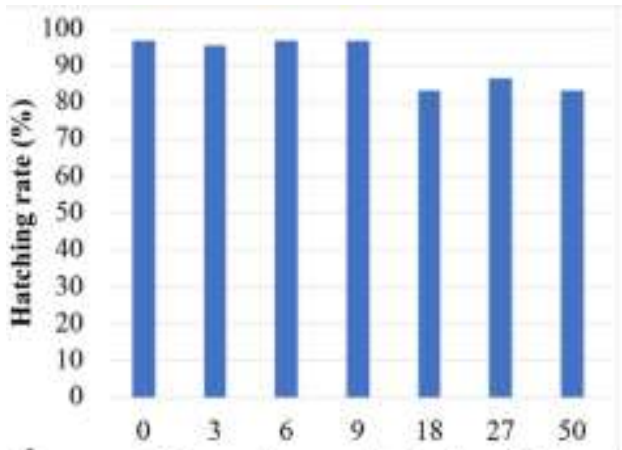

A

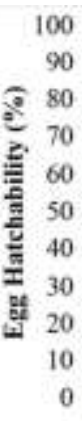

B

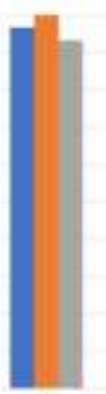

0

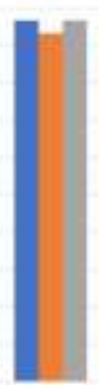

3

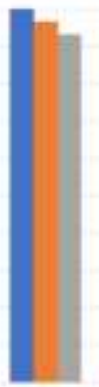

6

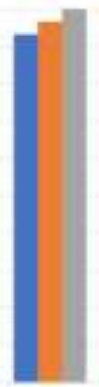

9

Detergent concentration $\left(\mathrm{mg} \mathrm{L}^{-1}\right)$

Fig. 1. Graph of egg hatching rate, A) Percentage of egg hatching rate all treatments, showing the high hatching rate on control and concentration of $3 \mathrm{mg} \mathrm{L}^{-1}, 6 \mathrm{mg} \mathrm{L}^{-1}$, and $7 \mathrm{mg} \mathrm{L}^{-1}$ respectively, and less on concentration of detergent of $18 \mathrm{mg} \mathrm{L}^{-1}, 27 \mathrm{mg} \mathrm{L}^{-1}$ and $50 \mathrm{mg} \mathrm{L}^{-1}$, respectively, B) The detail of egg percentage hatchability on each replication.

Referring to the result, this study conducted testing at the next exposure level of detergent concentrations of $18 \mathrm{mg} \mathrm{L}^{-1}, 27 \mathrm{mg} \mathrm{L}^{-1}, 50 \mathrm{mg} \mathrm{L}^{-1}$. The testing was carried out to ensure the effect of very high concentration of detergent on eggs hatchability. The results showed that the range percentage of egg hatchability after exposure to a detergent concentration of $18 \mathrm{mg} \mathrm{L}^{-1}, 27 \mathrm{mg} \mathrm{L}^{-1}$ and $50 \mathrm{mg} \mathrm{L}^{-1}$, were as follows; $83.33 \%, 86.67 \%$, and $83.33 \%$, respectively. These suggest a very high concentration of detergent lowers the percentage of fish egg hatchability.

Temperature could induce slow and rapid choriolytic enzyme production. At low temperatures $\left(<24{ }^{\circ} \mathrm{C}\right)$, enzyme production is slow to cause chorion softening, such that the embryo is difficult to penetrate. At high temperatures $\left(>38^{\circ} \mathrm{C}\right)$, rapid enzyme production causes premature hatching of embryos, which is for the most part, fatal to the embryo [13].

\subsection{Survival rates of the larvae}

The treatment on fish larvae decreased the fish larva survival rate for up to 1.5 mo (age). In the control, the survival rate was $98.85 \%, 96.63 \%, 95.48 \%$, and $90.84 \%$, from the start to the end of treatment. On the other hand, $3 \mathrm{mg} \mathrm{L}^{-1}, 6 \mathrm{mg} \mathrm{L}^{-1}$ and $9 \mathrm{mg} \mathrm{L}^{-1}$ of detergent treatment resulted in reductions in the numbers of surviving fish, in that respective order (Figure 2).

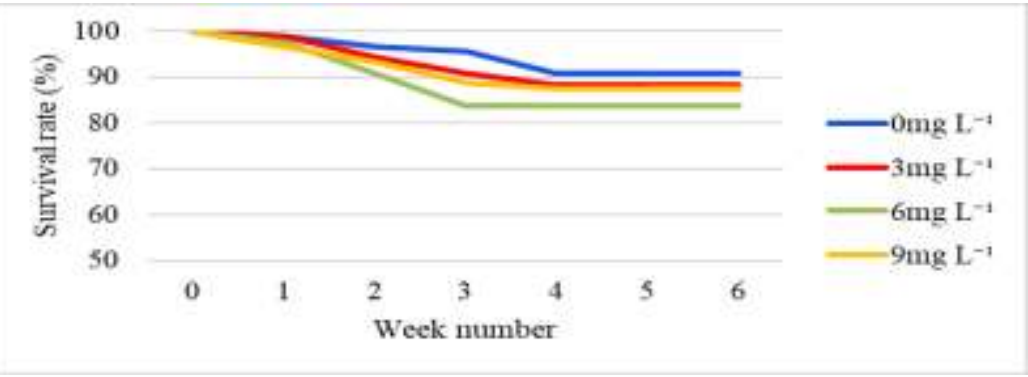

Fig. 2. Fish survival rate for $6 \mathrm{wk}$. 
The treatment showed no significant $(p>0.05)$ effect on fish survival rate, which suggested that the detergent concentration up to $9 \mathrm{mg} \mathrm{L}^{-1}$ was not strong enough to interfere fish metabolism. It was reported that moderate concentration of detergent caused severe effect on fish. However, it needs higher concentration $\left(1000 \mathrm{mg} \mathrm{L}^{-1}\right)$ to severe impact on the Anabas fish respiratory performance [14-18].

\subsection{The growth rate of the fish Larvae}

The growth rate of fish was measured based on total body length, and the ratio of head, body, and tail length. The variation of fish length each of the experiments were showed on Figure 3.

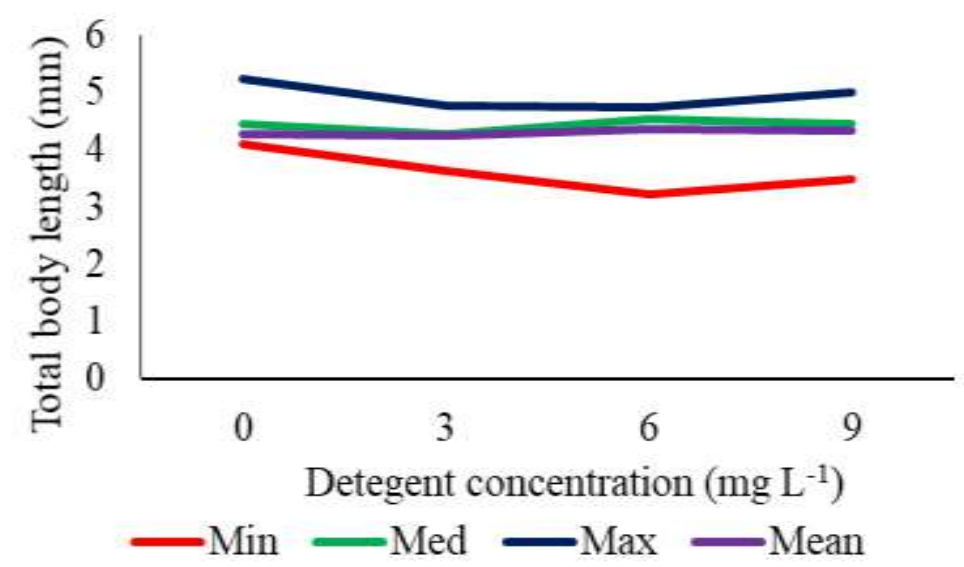

Fig. 3. Fish total body length for $6 \mathrm{wk}$.

The total body length of fish showed that control was longest body size of $4.45 \mathrm{~cm}$, which followed by $9 \mathrm{mg} \mathrm{L}^{-1}(4.37 \mathrm{~cm}), 6 \mathrm{mg} \mathrm{L}^{-1}(4.33 \mathrm{~cm})$ and $3 \mathrm{mg} \mathrm{L}^{-1}(4.24 \mathrm{~cm})$.

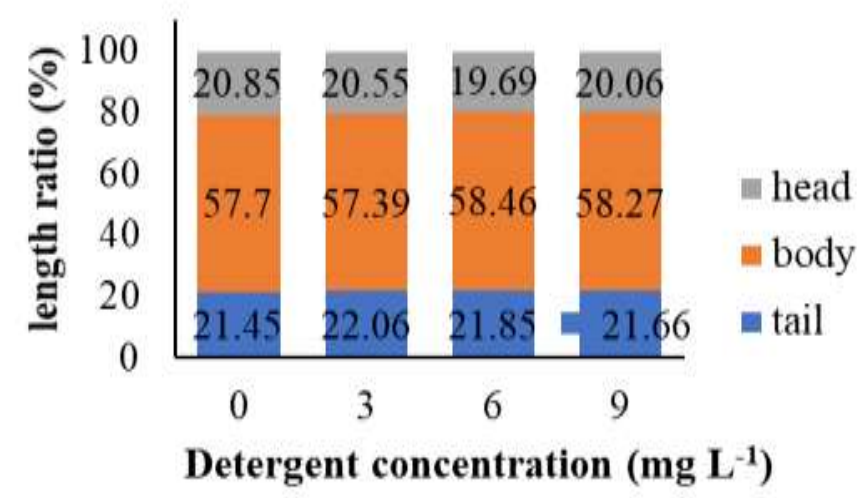

Fig. 4. The ratio of head, body and tail length of the fish.

The average head, body and tail length ratio showed the different results of different concentration of $0 \mathrm{mg} \mathrm{L}^{-1}, 3 \mathrm{mg} \mathrm{L}^{-1}, 6 \mathrm{mg} \mathrm{L}^{-1}$ and $9 \mathrm{mg} \mathrm{L}^{-1}$ (Figure 4). The average length percentage of head and to total body length ratio of $20.85 \%, 20.55 \%, 19.69 \%$ and 
$20.06 \%$, respectively. The body length to total body length ratio of $0 \mathrm{mg} \mathrm{L}^{-1}, 3 \mathrm{mg} \mathrm{L}^{-1}, 6$ $\mathrm{mg} \mathrm{L}^{-1}$, and $9 \mathrm{mg} \mathrm{L}^{-1}$, were $57.7 \%, 57.39 \%, 58.46 \%$ and $58.27 \%$, respectively. The tail length to total body length ratio of $0 \mathrm{mg} \mathrm{L}-1,3 \mathrm{mg} \mathrm{L}^{-1}, 6 \mathrm{mg} \mathrm{L}^{-1}$, and $9 \mathrm{mg} \mathrm{L}^{-1}$, were $21.49 \%, 22.06 \%, 21.85 \%$, and $21.66 \%$, respectively. The result showed that detergent concentration treatment of $0 \mathrm{mg} \mathrm{L}^{-1}, 3 \mathrm{mg} \mathrm{L}^{-1}, 6 \mathrm{mg} \mathrm{L}^{-1}$, and $9 \mathrm{mg} \mathrm{L}^{-1}$ did not significantly affect fish growth, and the ratio of head, body, and tail ( $\mathrm{p}>0.05)$.

\subsection{Vertebrae structure of the fish}

The vertebrae structure of all the fish were stained and observed for number and morphology. Vertebrae number of fishes were consisted of 33 vertebral bone in total, which consisted of three cervical, 11 precaudal, 16 caudal, and three caudal fin vertebrae (Figure 5).

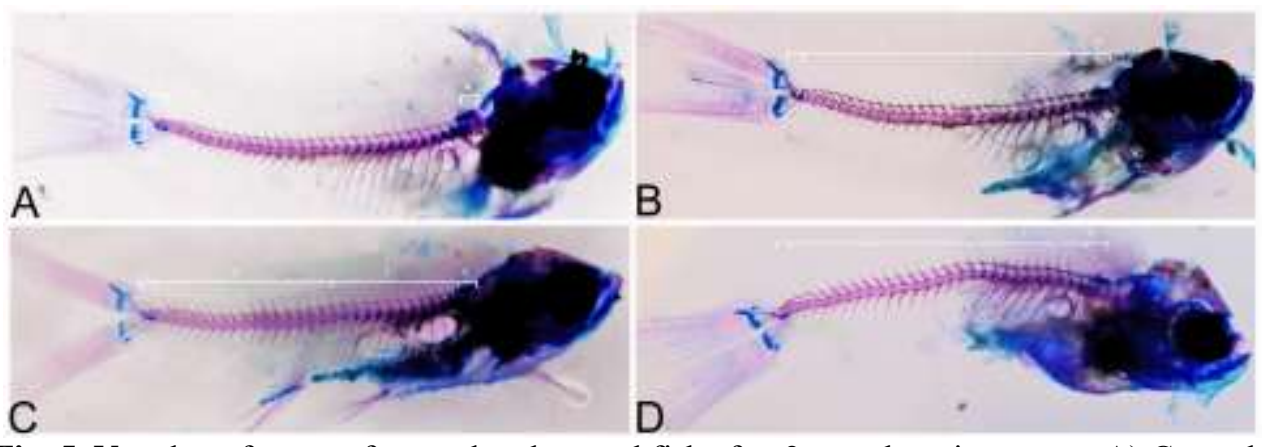

Fig. 5. Vertebrae feature of control and treated fish after 2-month maintenance: A) Control; B) $3 \mathrm{mg} \mathrm{L}^{-1}$; C) $6 \mathrm{mg} \mathrm{L}^{-1}$; D) $9 \mathrm{mg} \mathrm{L}^{-1}$. Showing the vertebrae arrangement of i) Caudal Fin Vertebrae; ii) Caudal Vertebrae; iii) Precaudal Vertebrae; iv) Cervical Vertebrae

The result showed that all concentrations of detergent treatment did not affect the vertebral segment number of fish. However, the $9 \mathrm{mg} \mathrm{L}^{-1}$ of detergent caused morphological abnormality of the vertebrae arrangement, especially in the area of precaudal bone.

According to Vashanti et al., detergents at a concentration of $3 \mathrm{mg} \mathrm{L}^{-1}$ within the space of $72 \mathrm{~h}$ exposures, were reduced in protein content from $3.14 \mathrm{mg} \mathrm{dL}^{-1}$ to $1.28 \mathrm{mg} \mathrm{dL}^{-1}$ in C. mrigala fish blood [2]. As a consequence, can inhibit the process of protein synthesis in the production of amino acids, one of which can be used for bone matrix formation, resulting in abnormal ossification.

\section{Conclusion}

It can be concluded in this study on wader pari (R. lateristriata) that detergent exposure to a concentration up to $9 \mathrm{mg} \mathrm{L}^{-1}$ does not affect egg hatchability, fish survival rate, larval growth rate, of the number of fish vertebrae. However, $9 \mathrm{mg} \mathrm{L}^{-1}$ of detergent concentration was observed to affect the vertebral morphology of fish larvae. 


\section{References}

1. M. Syaifullah, Pembuangan Limbah Laundry di Yogyakarta Ditertibkan [Control Laundry Waste Disposal in Yogyakarta]. [Online] from https://nasional.tempo.co/read/249971/pembuangan-limbah-laundry-di-yogyakartaditertibkan/full\&view $=$ ok (2010) [Acessed on 20 May 2019].

2. J. Vasanthi, S. Binukumari and N. Saradhamani, J. Pharm. Biol. Scie. 8,5:19-22(2013).

https://pdfs.semanticscholar.org/a2b3/08497549fd693b932c3fde7bb18aef6f25be.pdf

3. U. Zoller, P. Sosis, Handbook of detergents, part F: Production, CRC Press, (2008).p.624.

https://www.routledge.com/Handbook-of-Detergents-Part-FProduction/ZollerSosis/p/book/9780824703493

4. P. S. Topale, A. U. Ghaware, R. G. Jadhao, Int. Res. J. Sci. Eng. 1:10-12(2013). http://oaji.net/articles/2014/731-1396631673.pdf

5. U. Zoller, Handbook of detergents, Part B: Environmental impact, CRC Press, (2004).p.838. https://www.taylorfrancis.com/books/9780429215230

6. K. A. Najam, W. Bhowate, The Bioscan. 5,2:321-322(2010). https://pdfs.semanticscholar.org/c59f/37756b579c332cef4f224b45843bb10a07c6.pd $\underline{f}$

7. B. Isyaku, J. Solomon, DRJAFS. 4,12:351-360(2016).

https://directresearchpublisher.org/drjafs/abstract/effect-of-detergent-on-the-growthof-african-catfish-clarias-gariepinus/

8. B. Jezierska, K. Ługowska, M. Witeska, Fish physiol. Biochem. 35: 625-640(2009). https://doi.org/10.1007/s10695-008-9284-4

9. S. Santanu, Int. J. Pure Appl. Biosci. 1:36-41(2013).

http://www.ijpab.com/form/2013\%20Volume\%201,\%20issue $\% 205 / I J P A B-2013-1-$ 5-36-41.pdf

10. C. A. Zimring, W. L. Rathje, Encyclopedia of consumption and waste: the social science of garbage, Sage Publications, Inc., 2012.

https://sk.sagepub.com/reference/consumption-waste

11. Y. Wang, Y. Zhang, X. Li, M. Sun, Z. Wei, Y. Wang, et al., Scientific Reports

, 5:10107(2015). https://doi.org/10.1038/srep10107

12. M. Inouye, OJCARAJ. 16,3:171-173(1976).

https://doi.org/10.24540/cgafa.16.3_171

13. A. El-Gamal, Global Veterinaria, 3:80-90(2009).

http://www.idosi.org/gv/gv3(2)09/3.pdf

14. E. Mathew, P. Sunitha, P. L. Thomas, JESTFT. 5,3:1-3(2013).

http://www.indiaenvironmentportal.org.in/files/file/Phosphate\%20in\%20detergents $\% 20$ Kuttanad $\% 20$ Kerala.pdf

15. C. N. Eknath, Res. J. Anim. Vet. Fishery Sci. 1,9:14-19(2013). http://www.isca.in/AVFS/Archive/v1/i9/3.ISCA-RJAVFS-2013-052.pdf

16. N. Chandanshive, International Research Journal of Environment Sciences, 3:1-5, (2014). http://www.isca.in/IJENS/Archive/v3/i8/1.ISCA-IRJEvS-2013-210.pdf

17. E. Oyoroko, E. N. Ogamba, Biotechnol. Res. 3,59-64(2017).

https://www.futuredatum.com/wp-content/uploads/2019/11/59-64.pdf 
18. E. Idowu, A. Adewumi, A. Babalola. IOSR-JAVS. 10,67-75(2017).

https://pdfs.semanticscholar.org/0021/59170d687ce18543e28ffde7fc879d6a7e06.pd $\underline{\mathrm{f} \text { ? } \mathrm{ga}=2.224593310 .522309668 .1595752936-677940155.1595752936}$ 